\title{
Literatura e catolicismo na França (1880-1914) contribuição a uma sociohistória da crença
}

\author{
HervéSery \\ Tradução de Paulo Neves
}

Tanto a literatura como a religião têm a ver com a crença. 0 investimento individual nessas duas práticas, percebido como uma necessidade íntima, surge da crença e do desconhecimento coletivos de que esses objetos são portadores. A teleologia do comércio das almas e a teleologia do comércio da arte coincidem numa idêntica denegação do enraizamento sociohistórico de suas condições de possibilidades. A "C riaçãa" e o "C riador" originam-se num mais além inefável, 0 da inspiração. 0 s múltiplos intercâmbios entre 0 vocabulário da arte e 0 vocabulário sacramental atestam essa homologia. 0 ponto nodal da existência (social) da literatura, como 0 da religião, reside sobretudo na capacidade dessas práticas de se afirma rem como realidades transcendentes, isto é, relacionadas a uma lógica que não pertence ao domínio da causalidade, do explicável. Em outras palavras: que escaparia a toda racionalidade exterior.

Tentar compreender as relações da religião e da literatura é trazer à luz a sociogênese de dois sistemas de crenças, cujas lógicas próprias partil ham um poder similar de ordenar o mundo. Esses dois universos são governados por uma magia coletivamente produzida, solidificados em instituições e erigidos em dogma, magia reconhecida pelos indivíduos crentes tanto no poder da literatura como no poder da religião. $\mathrm{N}$ ão é fortuito que as resistências mais sólidas à objetivação pelas ciências sociais provenham desses dois domínios. Para compreender esses universos da 
1. Este artigo, que teve uma versão publicada nos $\mathrm{C}$ ahiers d'H istoire (E spaceM arx), 97, 2002, condensa uma parte da reflexão desenvolvida em H ervé (2004). Para a historiografia do catolicismo francês, consultar a síntese de Pelletier (1997). denegação não se deve cair nem numa visão que reduz as lógicas desses espaços aos meros interesses dos atores, nem no ponto de vista inverso, igual mente redutor, que elimina os móveis de poder e as lutas decorrentes. Assim, considerar a sociogênese das relações da religião (católica) e da literatura é desemaranhar as linhas de causalidades particulares de cada campo, que determinam em parte as tomadas de posição, sem esquecer que o campo literário, espaço de "mediações" das "determinações sociais que se exercem sobre a literatura", vê a literatura "elabora[r]-se aí segundo a lógica das mediações próprias a esse espaço" (B ourdieu, 1992; Viala, 1988, pp. 64-71). A teoria dos campos, com a representação dinâmica do social que ela subentende, permite considerar os fatos sociais numa perspectiva sociohistórica atenta às lógicas específicas, às estratégias próprias a cada campo (aoscruzamentos e trocas entre essas lógicas), ao mesmo tempo que permanece aberta à riqueza dessas histórias coletivas que os indivíduos produzem e das quais são também o produto.

D os dias que se seguiram à R evolução até as vésperas da Primeira G uerra M undial, clérigos e escritores católicos mobilizam-se para defender a preeminência da religião na sociedade. I nicialmente isolada, essa reivindicação, cujas principais etapas iremos reconstituir ${ }^{1}$, torna-se, na década de 1910 , sob a bandeira do "renascimento literário católico" , um dosfatosmarcantes do campo intelectual. Primeiro momento forte: a publicação de $G$ énie du christianisme (1802), de François-R ené de Chateaubriand, que oferece, do ponto de vistaliterário, umanova legitimidade ao catolicismo. D epois, o aba de Félicité de Lamennais impõe a necessidade de um pensamento católico ativo e que acompanhe as pesquisas científicas de seu tempo. $N$ um terceiro momento, a ação de LouisVeuillot, jornalista e ensaísta a serviço do papado, estabelece as modalidades de um engajamento intelectual leigo em nome do catolicismo. 0 positivismo parece dominar os "tristes anos" de 1880, para retomar a expressão do convertido Paul Claudel (1959). N o entanto, pela mediação complexade romancistaspsicológicoscomo Paul B ourget e da questão da responsabilidade do escritor, instala-se lentamente no mundo literário a idéia de um retorno do sentimento religioso. Graças à crise "modernista", que vê os clérigos se retirarem dos debates intelectuais, os anosde 1900 e 1910 são o palco de uma formainédita de mobilização intelectual católica: a partir de um trabalho de definição de uma estética fundada na religião, um grupo de jovensescritorescatólicosse erige em ponta de lança da reconquista de uma sociedade na qual a R epública leiga se impõe e devolve a religião ao domínio privado. 


\section{Um mal-entendido fundador: Génie du christianisme de Chateaubriand}

0 período pós-revolucionário é, devido às "novas condições sociais da produção intelectual" (C harle, 1990, pp. 20-24), nascidas do afrouxa mento das coerções da antiga sociedade, o momento do "advento de um poder espiritual leigo" (Bénichou, 1996; Ferguson, 1991, pp. 177-217). Essa sagração do escritor tem sua origem na concorrência feita ao poder intelectual da I greja pelo pensamento das Luzes, que põe o homem no centro da H istória. $\mathrm{O}$ filósofo das Luzes, "concorrente direto e sucessor confessado do teólogo", e o poeta (romântico), voltado a um magistério fundado no poder intrínseco de sua criação, tornam possível um novo "clericato" capaz de dar sentido ao mundo (B énichou, 1996, pp. 17-18).

D esde o C onsulado de Bonaparte (1899-1904) - do qual aC oncordata (1801) é um momento determinante, pois restitui à I greja um lugar na sociedade resultante da R evolução de 1789 - , as condições políticasfavoráveis ao catolicismo permitem o aparecimento de uma literatura contra-revolucionária animada pela religião. $\mathrm{A}$ poesia romântica, da qual $\mathrm{C}$ hateaubriand é um dos líderes, aproveita-se da hostilidade manifestada em relação à herança intelectual da R evolução (cf. I dem, pp. 145-149). M as se a corrente romântica participa da "sagração do escritor" , ao lado do "filósofo" nascido da revolução, ela se opõe a este último ao negar, em favor do sensível e do espiritual, o poder da R azão (C harle, 1990, p. 23).

Em 1802, o livro $G$ énie du christianisme, ou beautés de la religion chrétienne exprime as possibilidades artísticas do catolicismo (cf. Bénichou, 1977, pp. 105-120). Sem fundar uma estética completa, o apologista recentemente convertido inseri a religião no centro das interrogações artísticas e defende uma sensibilidade impregnada pela fé. Longe de ser "inimiga das artes e das letras, da razão e da beleza", a religião cristã "é a mais poética, a mais humana, a mais favorável à liberdade, às artes e às letras" (C hateaubriand, 1978, p. 469). A s fortes evocações do poeta reabilitam a Idade M édia e dão uma nova importância aos monges civilizadores ou ainda à figura do cava leiro cristão. São argumentos que renovam a visibilidade da religião nos meios literários e entre os leitores da burguesia, os quais contribuem para o sucesso do livro. A crescentemos que a demonstração estética que ajuda a trazer 0 católico para 0 âmago da civilização é acompanhada de um adendo político. C hateaubriand, rejeitando o que dissera em seu E ssai sur les révolutions (1797), desenvolve uma visão reacionária que "prepara a or- 
dem moral do Império" (R egard, 1978).

Por outro lado, 0 arrazoado de $C$ hateaubriand nega todo poder à ciência e recusa toda idéia de progresso; nisso também ele reforça uma recusa da herança revolucionária. Segundo o escritor, o H omem é incapaz de engendrar um absoluto. $0 \mathrm{G}$ énie du christianisme ajuda a solidificar a idéia de uma oposição entre ciência e religião, e a selar a aliança entre religião e literatura, precisamente contra a ascensão do poder científico (D hombres, 1989, pp. 313-334). Essa dualidade, redutível à oposição espírito e matéria, está no centro das lutas entre os defensores da cultura clássica e os da cultura científica, oposição reforçada pelas reformas do sistema de ensino feitas pela C onvenção (1792-1795), entre as quais a criação dos liceus públicos e das grandes escolas do Estado (Politécnica, Escola N ormal etc.). Essa política, que a seguir será contestada, contribui no entanto para enfraquecer o poder da I greja sobre a reprodução das elites.

Em 1904-1905, em seus cursos sobre a "história do ensino na França”, o sociólogo francês Émile D urkheim analisa o enraizamento desse antagonismo estrutural. D urante o século XVII, o ensino, jesuíta e universitário, articula se em torno da aprendizagem do latim e do grego, e transmite um saber feito de "tiposgeraise impessoais" .A ssim nasce um dostraços marcantes da literatura francesa. D e maneira mais ampla, segundo D urkheim, "nosso temperamento intelectual e moral" , mesmo durante o período pós-revolucionário, não se afastará de uma representação do "homem desapegado de todas as contingências nacionais e históricas" . 0 homem é considerado apenas por intermédio de "seus aspectos mais gerais [...] num meio unica mente povoado de abstrações, de tipos abstratos e simples, de entidades genéricas" (D urkheim, 1990, pp. 314-317). 0 s modos de pensamento assim produzidos, e também reforçados pela cegueira do sistema de ensino "às ciências da natureza física" , conduzem a uma rejeição da história e da ciência que pode satisfazer inteiramente 0 catolicismo, pois suas origens não estão no homem mas numa transcendência fundadora do mundo (Idem, p. 319).

Ainda de acordo com o fundador da escola francesa de sociologia, pode-se dizer que, ao cindir o mundo em dois - o "do pensamento, da consciência, da moral e da religião" oposto ao "mundo da matéria não inteligente, amoral, não religiosa" -, o cristianismo confere às "funções temporais" um lugar "inferior" (I dem, pp. 320-324). A R evolução francesa e as teorias filosóficas (materialistas) que a sustentam se posicionam contra essa cultura clássica. Ao cabo desse processo, que instala a figura do 
"erudito" (I dem, pp. 334-350), o espaço letrado vê-se dividido entre as letras, aliadas objetivas da religião e situadas portanto junto do idealismo, e uma visão do mundo contrária, da qual a ciência é a base. A pós a R evolução e diante da ascensão dos ideais positivistas,

[...] foi estabelecida como que uma aliança entre o humanismo e a Igreja. $0 \mathrm{~s}$ representantes do tradicionalismo, tanto em matéria religiosa como em matéria social e política, viram, com ou sem razão, no velho ensinamento literário o meIhor auxiliar do que Ihes parecia ser a doutrina sadia, enquanto, ao contrário, suspeitavam do ensino científico (Idem, p. 354).

A I greja liga seu destino à defesa de uma cultura clássica e latina, da qual a abstração, as tentações universalizantes, a a- historicidade e o papel civilizador de R oma constituem outros tantos fundamentos à sua dominação espiritual do mundo, ao reinado do espírito sobre a matéria e da alma sobre o(s) corpo(s). Essa configuração é particularmente propícia para atrair escritores situados, em razão de suas disposições, no pólo conservador do campo literário.

\section{Saber e dogma: 0 abade Lamennais}

0 romantismo cristão iniciado por C hateaubriand, simbiose complexa entre espiritualidade e retorno à ordem, é uma primeira etapa importante da restauração do catolicismo no domínio intelectual. Félicité de Lamennais (1782-1854), um padre ordenado em 1816 sem ter freqüentado o seminário em razão dos distúrbios revolucionários, reconhece as contribuições de $\mathrm{G}$ énie du christianisme, mas deplora o perigo de uma adesão lírica à religião. D ecerto $C$ hateaubriand mostra 0 quanto 0 cristianismo ilumina a "razão" , mas ele se limita a celebrar suas capacidades de suscitar os "arroubos da alma [...] tão divinamente quanto os deuses deV irgílio e de H omero" (Lamennais apud Derré, 1962, pp. 8-11). Sem negligenciar a espiritualidade, Lamennais orienta- se para a formação de uma elite clerical capaz de enfrentar os desafios intelectuais do tempo.

A importante acolhida de seu $E$ ssai sur l'indifférence en matière de religion (1817 e 1820), dedicado à demonstração da existência de $D$ eus, permite a Lamennais afirmar, com o apoio de seus discípulos, formados graças à constituição de uma Congregação de São Pedro (1828), a superação das filosofias individualistas em favor da tradição cristã. 0 catolicismo é a 
culminação dosprincípios organizadores de uma religião natural e primitiva, anteriores aos dois Testamentos. Portanto, é o princípio unificador da história da H umanidade, o único detentor de uma "razão geral" . Em outras palavras, a R evelação cristã é um sistema organizador superior e sem fal ha: de fato, como princípio de continuidade que orienta a história, ela funda uma fé que se apóia num sentido comum à maioria dos homens (mesmo os pagãos lhe deram sua contribuição). Essas crenças gerais estabelecem a verdade cristã que se encarna na autoridade da I greja e justificam a idéia de um progresso do pensamento no seio do catolicismo. Conseqüentemente, para Lamennais, os católicos podem reconciliar a ciência e a fé e animar o debate científico (cf. Le Guillou, 1996, pp. 377-379). U ma so ciedade que autonomiza a razão tende necessariamente à sua ruína. $N$ essa perspectiva, a autoridade do Estado depende da religião, do mesmo modo que a organização eclesial se divide entre os portadores da autoridade, os clérigos e os outros, os leigos (cf. Tranvouez, 1975, pp. 105-142). N isso Lamennais situa-se na continuidade dos pensamentos tradicionalistas de B onald, que teoriza a incapacidade do shomens de constituir uma sociedade, e de D e M aistre, que em D o papa (1819) esclareceu para um vasto público, e portanto fora dos debates especificamente teológicos, osfundamentos da autoridade da Santa Sé (cf. M acherey, 1996, pp. 76-77 e pp. 441-442).

Lamennais e seus seguidores, convencidos da força intrínseca de um conhecimento escorado no catolicismo, vêem-se como uma vanguarda erudita engajada numa contra-Enciclopédia, cuja meta é conquistar a adesão das elites. $N$ ão demorou muito para que o engajamento de Lamennais esbarrasse em certos limites no seio da I greja. A pesar de sua oposição aos bispos galicanos da França, que recusam se submeter ao poder central romano, e de sua defesa do ultramontanismo então em formação, Lamennais discorda das concepções papais em matéria política. Ele chegará mesmo a pregar uma separação entre I greja e Estado para dar à religião uma liberdade de ação desembaraçada dos entraves políticos. A encíclica antiliberal M irari Vos (1832) (cf. Aubert, 1965, pp. 81-93) marca uma ruptura e leva-0 a afastar-se publicamente da I greja com seu livro Paroles d'un croyant, publicado em 1834 e rapidamente condenado pelo Vaticano. $\mathrm{N}$ ão obstante essa rejeição, o movimento que ele iniciou terá uma descendência fecunda. Seus discípulos e continuadores intelectuais prosseguirão sua ação no domínio litúrgico (dom Guéranger), social (Frédéric $\mathrm{O}$ zanam), religioso (H enri de Lacordaire e Emmnuel d'Alzon) 
ou ainda da ciência (François R io e o abade M igne).

Todavia, a rejeição autoritária pela mais alta hierarquia católica (e em nome da política) das veleidades de reconquista intelectual de Lamennais reforça a percepção de uma I greja que entrou em luta contra a sociedade moderna, especialmente entre escritores que aderiam ao cristianismo ou dele se aproximavam por intermédio do romantismo. Por outro lado, ao reprimir toda possibilidade de atividade política, essa crise abre aos católicos que Lamennais inspirou a possibilidade de orientar sua ação para iniciativas decididamente religiosas. N o mínimo, ele impõe um modelo (clerical) em sua vontade de demonstrar a atualidade (intelectual) do catolicismo.

\section{Figura do escritor leigo a serviço da instituição: Louis Veuillot}

O leigo LouisVeuillot encarna uma adesão total ao poder romano, cuja recusa de todo compromisso com o "mundo moderno" defende sem descanso. $\mathrm{N}$ a linha do ultramontanismo de Lamennais, mas sem seguir seu liberalismo, a ação de Veuillot contribui para impor a figura do escritor leigo engajado a serviço do catolicismo.

A trajetória de Veuillot é marcada pelo episódio revolucionário que empobrece sua família. Esse autodidata, nascido em 1813, é filho de um tanoeiro de província que se torna operário em Paris. A pós um modesto começo como redator de notícias mundanas, por intermédio de um conhecido do notário para quem trabalha, ele galga escalões e torna-se um dos escritores mais destacados da imprensa parisiense. Aos 25 anos, durante uma viagem a $\mathrm{R}$ oma, converte- $\mathrm{se}$. $\mathrm{A}$ ascensão relâmpago causa- Ihe certa desilusão do jornalismo e ele é tentado pela literatura. A té essa ruptura, Veuillot descreve sua vida como uma série de etapas sem referencial, de um emprego a outro, "sempre obrigado a partir no momento em que, sentindo meu coração enraizar-se, era-me doce crer que eu poderia ficar" (R ome et L orette [1841], apud Cough, 1986). Seu êxito social o afastou de seu meio de origem e ele parece encontrar no catolicismo um ancoradouro.

D epois de sua temporada em $\mathrm{R}$ oma, ele escreve dois romances que falam de sua conversão (L es pè̀erinages de Suisse, 1839, e R ome et L orette, 1841), ao mesmo tempo que colabora em vários periódicos católicos. Em junho de 1839, integra a redação de um jornal em declínio, L'U nivers R eligieux, que em poucos anosele transforma no principal órgão do cato- 
licismo ultramontano e intransigente. Além dos textos oficiais, da história do catolicismo ou da teologia - informações cuja divulgação é determinante para organizar a obediência à autoridade papal - , L'U nivers propaga a atualidade do catolicismo, especialmente junto ao clero de província.

Ao longo dos artigos, incansavelmente, Veuillot denuncia as pretensões da ciência, os livres pensadores e o socialismo, a nefasta herança política da R evolução, os compromissos dos galicanos e a burguesia liberal que explora o povo. A sinovações tecnológicas e a sujeição do homem ao materialis mo são também objeto de suas cóleras, a exemplo de vários outros católicos antimodernos e reacionários (cf. Lagrée, 1999, pp. 35-42). Seu zelo de convertido é alimentado pelo pensamento contra-revolucionário de $\mathrm{De}$ $M$ aistre e de Donoso Cortès, de quem é amigo. Aos católicos liberais, Veuillot nunca deixa de contrapor suas próprias origens populares, de zombar de suas discussões de salão, dos compromissos sucessivos desses aristocratas, "filhos da Sorbonne", membros do Instituto e da A cademia. 0 utra constante de seu pensamento é um anti-semitismo virulento: nisso ele também haverá de inspirar várias gerações de escritores católicos, clérigos ou leigos (cf. Pierrard, 1999, pp. 67-70, e 1997, pp. 61-64). L'U nivers segue com atenção os debates iniciados no seio das hierarquias eclesiais francesa e romana, que giram em torno das lutas entre galicanos e ultra montanos. M onsenhor D upanloup, bispo de 0 rléans, e monsenhor Sibour, bispo de Paris, ambos eminentes representantes da corrente liberal e galicana, enfrentarão LouisVeuillot na questão do controle da imprensa pelos bispos. $C$ ada momento de tensão entre os galicanos e $R$ oma é ocasião paraVeuillot firmar sua posição: o escritor leigo afirma seu poder graças aos conflitos estritamente clericais que opõem o poder romano à hierarquia católica francesa. Ao defender o papa, cujo poder é ainda frágil (a infalibilidade pontifícia só é pronunciada em 1870),Veuillot contribui para dar uma realidade ao papel dos pensadores e dos escritores no seio da Igreja.

Tomemosum exemplo dessas múltiplas polêmicas. Em janeiro de 1853, uma série de artigos no jornal de monsenhor Dupanloup, L'ami de la religion, contestando um livro de D onoso C ortès, suscita a indignação de Veuillot. Para defender aquele que considera "o último dos grandes adversários do século XVIII", Veuillot responde que D onoso C ortès, embora leigo, traz em defesa do catolicismo argumentos verdadei ros e cumpre melhor sua missão do que alguns teólogos (apud C ough, p. 246). 0 arcebispo de Paris, aproveitando a ocasião para conquistar terreno no cam- 
po ultramontano, proíbe a leitura de L'U nivers aos membros do clero de sua diocese. Veuillot é acusado de querer arrogar-se o poder dos bispos, como atesta esta carta de monsenhor Sibour à imprensa, datada de 23 de fevereiro de 1853:

A demagogia, reprimida na sociedade civil, irrompeu dentro da I greja por intermédio de uma parte da imprensa chamada católica. A demagogia dentro da Igreja é o presbiterianismo e o laicismo que querem tomar o lugar do episcopado no ensinamento e no governo das almas. [...] 0 laicismo afirma se como um poder que, a despeito de todos os princípios, dá lições ao episcopado nos assuntos eclesiásticos. [...] A hierarquia sagrada deve acabar com essa tirania leiga (apud Pierrard, 1997, p. 22).

Para defender-se dessas críticas, o jornalista vai a R oma buscar o apoio do papa. Pio IX o recebe e encoraja sua ação, mas lamenta que essas polêmicas dêem uma imagem ruim da I greja, e deseja suprimi-las. A imprensa parisiense publica uma carta do secretário particular do papa que pede a suspensão da condenação pronunciada contra L'U nivers. O saliados do bispo de Paris não sossegam, mas em $1^{2}$ de abril de 1853 aparece a encíclica Inter M ultiaiples, que recusa em bloco as posições galicanase, conseqüentemente, fortalece Veuillot. A seu favor, os bispos são intimadosa

[...] tratar com toda a predileção os homens que, animados do espírito católico e versados nas letras e nas ciências, consagram suas vigílias a escrever e a publicar livros e jornais para que a doutrina católica seja propagada e defendida, para que as opiniões e os sentimentos contrários a esta Santa Sé e à sua autoridade desapareçam (apud Cough, pp. 257-258).

A serviço do papa, contra os bispos galicanos, a ação de LouisVeuillot contribui para o nascimento "de um poder paralelo à hierarquia, 0 que mais tarde serão os chamados teólogos sem mandato" (Poulat, 1984, p. 140). Se a hierarquia romana sempre esteve atenta em denunciar a liberdade de imprensa, progressivamente - em particular sob o pontificado de Leão XIII (1878-1903) - ela estimula o desenvolvimento da imprensa confessional e busca enquadrá-la com vigilância. L'U nivers constitui uma etapa chave dessa apropriação. Seus assinantes o consideram um órgão "oficioso" , mas à margem de R oma, e seu sucesso deve-se também a isso. Essa dupla constrição confere a L'U nivers sua autoridade e uma certa li- 
berdade (cf. Gadille, 1969, p. 276). Veuillot reivindica a função de portavoz ativo. Ele afirma em 1843: "Fazemos política, queremos fazê-la, de modo nenhum estamos descontentes por fazê-la. N outrostempos, a I greja precisou de um braço secular; hoje ela precisa de uma voz secular; nós seremos essa voz" (apud Pierrard, 1997, p. 87). Em outra parte, ele diz escrever "para formar na França uma opinião, não que governe os bispos, mas que forneça aos bispos os meios de governar" (apud G adille, 1969, p. 261). 0 escritor adquire o poder de orientar a opinião do clero, de intervir nos debates internos da Igreja e junto à opinião pública, à qual 0 crescimento da imprensa confere uma nova importância.

\section{Positivismo, naturalismo, romance psicológico e retorno do sentimen- to religioso nos meios intelectuais}

Será que nos anos de 1880, como escreve mais tarde um especialista da literatura católica, 0 abade Jean C alvet, o cristianismo literário (C hateaubriand, Lacordaire, M usset) é “varrido pelo positivismo" (1922, p. 291)? Segundo suas opções próprias, Auguste Comte, Émile Littré, M arcelin Berthelot ou Paul Bert postulam, para retomar a expressão do filósofo ÉtienneVacherot, que "a ciência é a luz, a autoridade, a religião do século XIX" (Schnerd, 1968, pp. 99-110). N o que diz respeito ao catolicismo, os avanços da história, da antropologia, da etnografia ou da arqueologia permitem reconsiderar a história das religiões e, de fato, contestar aos clérigos o monopólio do discurso sobre o religioso. Para Ernest R enan, cujo $L$ a vie de Jésus (1863) obtém um grande sucesso, "os estudos críticos rela tivos às origens do cristianismo só dirão sua última palavra quando forem cultivados num espírito puramente leigo e profano" (1974, p. 39). A epistemologia positivista ataca os fundamentos da história da Igreja, e portanto a autoridade de sua tradição.

N o domínio literário, o positivismo orienta o movimento naturalista. Para sua $\mathrm{H}$ istoire naturelle et sodale d'une famille sous le Second E mpire (18701891),Zola recorreà pesquisa. A ciênciaé investida de um prestígio real, em detrimento de esquemas de pensamento anteriores como o romantismo. A legitimidade desse paradigma provém igualmente das mudanças das condições de acesso àcarreira literária. 0 smeiosde chegar a uma posição reconhecida no campo intelectual devem "ser buscados agora na nova fonte de legitimidade representada pela ciência, portanto em sua encarnação, o cientista" (Charle, 1990, pp. 35 ss.). A meritocracia republicana, apesar de 
seus limites, e a concorrência dosuniversitários al imentam a visão de uma cultura clássica ameaçada pelo cientificismo. 0 "nascimento do romance psicológico" é uma resposta a essas transformações (Ponton, 1975, pp. 6675). A o se reapropriarem do gênero romanesco e ao Ihe darem uma legitimidade social e cultural, contra os naturalistas menos dotados social mente, os "psicólogos" reagem ao enfraquecimento das promessas de uma carreira poética, num momento em que a produção literária cresce como nunca. A "estética psicológica" permite reapropriar-se da herança de R enan e de Taine, mobilizando os capitais sociais e escolares de seus promotores numa estética em que a fineza, o gosto da análise, o senso das hierarquias são virtudescardinais, em oposição à "vulgaridade" naturalista.

Paul Bourget, um dos "filhos deTaine entre ciência e moral", é quem realizará o essencial da"reinterpretação espiritualista" do positivismo com seu célebre romance L e disciple (1889). A história trágica do jovem discípulo proveniente de um meio modesto, que se torna assassino porque é incapaz de dominar o saber abstrato do cientista que admira, pretende ser a demonstração da necessária recusa da figura do cientista profético em nome de um "paradigma da responsabilidade" (Sapiro, 2002, pp. 219-240). 0 escritor não pode mais posicionar-se fora da ordem social. 0 disápulo suscitará uma polêmica entre Ferdinand B runetière eA natole France. Este último afirma os direitos da estética e da liberdade do artista: toda tutela da filosofia vai contra o progresso. Brunetière recusa essa liberdade em nome da impossibilidade de conceder qualquer autonomia às idéias (cf. Loué, 1996, pp. 44-61).

A nticientificismo, defesa da cultura clássica contra os "bárbaros" da escola republicana, psicologia que abre as portas ao espiritualismo, recusa da liberdade da arte em favor da responsabilidade social são alguns dos elementos que vão entrar em ressonância com o papel que a I greja então se arroga para a conservação da ordem social e dos valores clássicos. Essa configuração explica que vários escritores se aproximem da Igreja, chegando às vezes a converter-se, como Léon Bloy (convertido em 1897), Paul C laudel (1886), Paul Bourget (1889), Joris-K arl H uysmans (1892), François C oppée (1897) ou ainda Ferdinand B runetière (1898- 1900). Esses retornos à fé, seguidos nos anos de 1900 e 1910 de um movimento de conversões de várias dezenas de artistas (Gugelot, 1998), são para a I greja um poderoso argumento de apologética, utilizado como prova de uma nova atualidade do catolicismo. A partir dos anos de 1880 floresce uma retórica de "renascimento católico". L e roman russe (1886) de M elchior deVogüe, ar- 
razoado em favor de um moralismo literário atento à psicologia e às sensações interiores, marca o começo do descrédito do naturalismo (cf. R aimond, 1967, pp. 25-41). A leitura das revistas literárias e da imprensa da época permitiria multiplicar os exemplos daqueles que, como 0 abade D enis, em L'université catholique, apontam "o advento provável de um renascimento cristão na França" (1892, pp. 69-113). N o entanto, esses sinais de um retorno religioso são difíceis de manejar na medida em que podem significar uma mudança de percepção da I greja católica pelos grupos afetados, sendo ao mesmo tempo um elemento que faz crescer esse fenômeno. Embora se alimente de lógicas sociais oriundas de mudanças estruturais, a retórica do "renascimento (literário) católico" possui a força das profecias que se cumprem (self-fullfilling prophecy).

A aliança objetiva de escritores com o combate da instituição católica fixa-se especialmente na capacidade da I greja de definir uma moral social que a ciência acreditara poder elaborar. D iante da liberalização da imprensa e da maior influência da produção intelectual sobre massas cada vez mais escolarizadas, a teoria da responsabilidade definida por Bourget (e aprovada por Brunetière) permite a esses escritores definir seu papel ao lado do clero. C ontra os positivistas, a posição dos neocristãos- para além de sua diversidade - pode ser lida como uma vontade de alinhar-se com uma ciência e uma razão devolvidas à sua verdade, porque subordinadas à moral. M oral cujo fiador é a tradição católica mantida pela Igreja de R oma. O s pontos de vista político e literário juntam-se de maneira perfeita na defesa da instituição eclesial: ao orgulho do individualismo - confundem-se aqui as ambições "egoístas" de ascensões so ciais alimentadas pelo ideal da meritocracia escolar e o "egoísmo" do escritor que prega a arte pela arte -, os escritores convertidos ou próximos do catolicismo opõem a virtude do enquadramento moral que submete tanto 0 cidadão como 0 artista a uma força coercitiva, cujo referente não é o homem, mas D eus. Às veleidades dos naturalistas, adeptos de uma arte social crítica, e aos defensores da arte pela arte (o Parnaso e o simbolismo), desprendida de toda coerção social, os escritores (neo)católicos respondem com a submissão a uma ordem moral que não apenas não limitaria a prática artística, mas Ihe daria sua verdadeira vocação.

Esse trabal ho de redefinição da herança positivista em nome da moral, operado por Bourget e B runetière, possui uma descendência identificável. Em 1912, quando o simbolista $H$ enri de R égnier entra para a A cademia, FrançoisVeuillot, jornalista de $L$ a $C$ roix e filho de LouisVeuillot, explica a 
seus leitores que há "dois campos" entre os escritores, os "soldados da pena" : "U ns reconhecem que a vida do homem não possui em si mesma nem sua lei nem sua finalidade; outros pretendem que a existência humana encontra somente em si sua regra e sua meta". A "neutralidade literá ria" dos partidários da arte pela arte é o equivalente do "sistema equívoco e pernicioso" criado pelo Estado leigo para educar a juventude. É uma "conjuração anticristã" a serviço de uma moral pagã (Veuillot, 1912, p. 1). Com o enfraquecimento do positivismo e a ascensão concomitante da corrente de escritores psicológicos e neocristãos (Paul Bourget encarna essa dupla faceta), atam-se os fios de uma possível intervenção de escritores a serviço da I greja.

\section{A afirmação dos leigos: crise "modernista" e retirada do clero dos debates intelectuais}

$\mathrm{N}$ o final dos anos de 1880, o regime republicano, que resistiu a várias crises importantes, entre elas o episódio boulangista², está agora solida mente instalado. A s leis escolares, a interdição das congregações, a morte do conde de Chambord em 1883, que diminuem as esperanças dos monarquistas de voltar ao poder, o fracasso do partido católico nas eleições de 1885 e a situação européia pouco propícia a um desfecho favorável ao papa na questão romana são alguns dos elementos que levam o pontífice Leão X III a pedir aos fiéis franceses para aceitar 0 "governo que a França escolheu". Em fevereiro de 1892, a encíclica $\mathrm{E} m$ meio às solicitudes define essa A desão que abre, apesar das reticências suscitadas na alta hierarquia eclesial, um espaço de intervenção para os católicos na sociedade, especialmente para os leigos. 0 s efeitos desse apaziguamento no terreno político são reforçados pelo novo entusiasmo com que a encíclica $R$ erum N ovarum (1891) já havia impulsionado a ação dos católicos no terreno social. 0 poderio crescente dos partidos operários na Europa e a repercussão favorável de seu discurso "messiânico" demonstram aos católicosa urgência de empreender, para além da caridade cristã, obras capazes de conquistar o proletariado. Albert de $\mathrm{M}$ un, inicialmente com a $\mathrm{O}$ bra dos Círculos 0 perários, criada logo após a derrota de 1870, em associação com o monarquista leplaysiano ${ }^{3} R$ ené de laTour du Pin, e depois com a A ssociação $C$ atólica da Juventude Francesa (ACJF), constitui um exemplo dessa forma renovada de mobilização. Essa militância, encorajada pelo papa e renovada em suas formas, manifesta-se não apenas por uma pre-
2. Tentativa de derrubar aTerceira R epública francesa, na década de 1880, chefiada pelo general G eorges Boulanger (1837-1891) (N. doT.).

3. Leplaysiano refere-se àspropostas de Frédéric Le Play (1806-1882), sociólogo e político, fundador de uma"economia social" preocupada com o desenvolvimento moral da sociedade (N . do T.). 
sença maior dos leigos nas primeiras filas das obras sociais católicas, mas também por uma competência doutrinal mais completa deles, essencial para que possam se afirmar em suas relações com os clérigos.

Essa primeirafase da"A ção católica" - a expressão só aparecerá em 1907 sob a pena de Pio X - marca o início da"era militante" do laicato (Pierrard, 1988, pp. 123-146). Por sua proliferação e pelos conflitosque não deixarão de surgir com a hierarquia (entre os quaisa condenação, em 1910, do movimento "Le Sillon", fundado por M arc Sangnier), essas organizações definem o papel dos leigos num quadro que não é de subordinação estrita ao clero.A separação entrel grejae Estado, em 1905, confirma para aSantaSéa necessidade de incentivar as 0 bras: confinada ao domínio privado, afastada do poder político, a I greja vêna ação social o meio de manter-se na socieda de. Em 24 de dezembro de 1909, em uma carta a Louis M assignon, o convertido Paul Claudel constata que "este tempo parece ser o dos leigos. Vejam que papel desempenham de cem anos para cá, sem comparação com nenhuma outra época, C hateaubriand, D e M aistre,Veuillot, 0 zanam e outros". Ele confirma assim uma longa evolução.

Escritores, jornalistas e publicistas assumem essa nova dimensão do apostolado leigo. 0 desenvolvimento da imprensa católica, e seu sucesso (com o diário $L$ a $C$ roix desde 1880), é um elemento decisivo dessa evolução.V inculado ao das 0 bras, esse êxito é vivido como um "renascimento" do catolicismo que, em torno da figura do papa, conseguiu recriar uma dinâmica de reconquista.

São os efeitos da crise "modernista" - a qual deve ser compreendida como a refração, segundo o prisma dos desafios clericais, da contestação da religião católica no terreno das idéias ("modernas") - que confirmam a possibilidade de ver, ao lado dos leigos católicos engajados no domínio social, a afirmação do papel dos escritores católicos para a defesa da I greja. A o obrigar seus clérigos envolvidos no trabalho intelectual a se retirar dos debates científicos com os não-católicos, a alta hierarquia católica abre aos escritores possibilidades de se colocarem a seu serviço. E isso sobretudo na medida em que a crise "modernista" conhece as lutas surgidas do $C$ aso D reyfus (1898), que marca o "nascimento dos'intelectuais'" (C harle, 1990), ou seja, a afirmação de sua autonomia e de seu direito de intervenção nos assuntos públicos em nome da especificidade de sua prática. Essa recomposição do campo intelectual, e do subcampo intelectual católico do qual os clérigos estão excluídos em razão da "crise modernista", cimenta a aliança dos escritores católicos e da instituição eclesial numa luta partilha- 
da pelo retorno a uma sociedade cristã.

Para além das questões relativas à autonomia dos intelectuais, o C aso $D$ reyfus reconstitui o confronto entre $R$ epública el greja. D esde o início, os católicos alinham-se em massa no campo antidreyfusista. A aproximação iniciada pela A desão, e não desprovida de desconfiança e ambigüidade de parte a parte, se manteve. $O$ C aso D reyfus engessa a política dos republicanosem torno da questão clerical (cf. Levillain, 1994, pp. 411-450). 0 antisemitismo da imprensa católica, em nome do militarismo, e a ausência de reação da hierarquia episcopal reforçam a idéia de um bloco católico que recusa a revisão do processo do capitão D reyfus como um meio de contestar o poder estabelecido. A oposição entre os republicanosleigos e os católicos se agrava novamente nessa ocasião. Em 1905, a lei de separação da I greja e do Estado constitui um traumatismo para muitoscatólicos. Ela participada tendência à autonomização do espaço de ação dos leigos, colocando em segundo plano a questão religiosa, em proveito das preocupações sociaise internacionais (cf. M ayeur, 1991). N o mundo intelectual a clivagem também se agrava. Escritores católicos, ou que recentemente se afirmavam como tais, a exemplo de Bourget e Brunetière, posicionam-se à frente do combate antidreyfusista, juntamente com o campo conservador.

Em que consiste essa "crise modernista" que ata a relação da I greja com os "intelectuais"? Em primeiro lugar, deve-se compreender que ela é a culminação de "um antagonismo sociorreligioso" que, durante todo 0 século XIX, vê confrontarem-se "a fé e a razão, a teologia e a ciência, as antigas tradições e o espírito moderno, a I greja e o mundo temporal, e no extremo - as duas Franças" (Poulat, 1996, p. 8). N a origem, é a vontade de estudiosos católicos, clérigos e leigos, de levar em conta as inovações científicas mais recentes. A oposição que os especialistas dos textos sagrados vão encontrar no núcleo da I greja os obriga a repensar sua relação com a instituição. C ria-se uma tensão entre as modalidades de validação da instituição clerical - em conformidade com a doutrina - e as modalidades da ciência, cuja finalidade declarada é a racionalidade. As condenações sucessi vas de cientistas católicos levam ao isolamento e à exclusão dos clérigos, não legitimados no plano científico, o que suscita a questão dos fundamentos e dos motivos do poder eclesiástico.

No centro da tormenta estão os trabalhos de história crítica do abade Alfred Loisy: 0 historicismo que ele sistematiza nas ciências religiosas afasta o sobrenatural em nome da competência histórica. Esse método põe em questão a história sagrada e suas origens divinas transmitidas pela tradição 
a partir dos textos sagrados: o dogma não é imutável e pode ser referido a uma configuração particular da história. M as qual é a autoridade de um dogma que admite a possibilidade de uma mudança de natureza? Para além das condenações que atingem os modernistas - entre os quais Loisy, excomungado em 1908 -, esses debates de eclesiásticos se inscrevem num contexto maisamplo:

[...] ao mesmo tempo que o povo da cidade e do campo se separa da religião ancestral, a cultura escapa ao controle tradicional da Igreja, e a concorrência mesma em seu próprio domínio irá opor as "ciências religiosas" às "ciências sagra das" (Poulat, 1996, pp. 613-620).

Em 1907, com o decreto L amentabili eaencíclicaPascendi,Pio X proíbe o "modernismo". Para erradicar o perigo, que vai muito além das idéias de Loisy, o ensino dosseminários e a produção intelectual católica são postos sob vigilância (cf. Serry, 2003, pp. 89-109). 0 regime de denúncias e de repressões, as quais caracterizam essa crise, não é redutível a um confronto dual entre partidários do progresso e defensores de um passado ideal.Amplamente instrumentalizado, o antimodernismo, que também atinge os meios do catolicismo social e dos escritores, contribui - no momento do C aso D reyfus - para excluir da ação intelectual os clérigos intelectuais. D esconsiderada por essa dependência (orgânica) aos arbítrios da instituição, a presença ativa do clero no campo intelectual se contrai. C om C laude Langlois, pode-se afirmar que, para existir como tal no campo intelectual, isto é, como portador de uma especificidade, o "intelectual católico" deve se definir por "sua capacidade de refletir e tomar posição sobre a relação atual de sua I greja com os problemas do mundo contemporâneo", assim como por "sua capacidade de autonomia em relação à instituição e por sua legitimação científica no exterior da I greja" . Essa dupla orientação é então impossível de satiffazer, pois a instituição eclesial recusa a seus clérigos qualquer autonomia, mesmo relativa. Ela Ihes nega qualquer autoridade que teria emanado do "domínio das ciênciasfilológicas, históricas e filosóficas [e] Ihes teria permitido chegar ao estatuto de intelectual no seio da I greja católica" (Langlois, 1997, pp. 213-223).

Em contrapartida, essa configuração oferece a ocasião, a uma jovem geração de pretendentes católicos à carreira literária, de reivindicar uma "ação intelectual" diretamente pensada como complemento da ação social incentivada pela $\mathrm{R}$ erum $\mathrm{N}$ ovarum e as $\mathrm{O}$ bras. $\mathrm{A}$ retirada forçada dos clérigos deixa um vazio que os escritores poderão ocupar. 


\section{Um "escritor católico" para uma "literatura católica"?}

Do ponto de vista de sua especialidade, os escritores apresentam a vantagem de não levantar questões de doutrina. A literatura não detém a capacidade de questionar o dogma, ao contrário da filosofia. D epositário de uma cultura clássica da qual o catolicismo quer ser fiador, o escritor, dotado de um poder profético, permite uma presença católica no campo intelectual. $\mathrm{N}$ um momento em que 0 acesso ao ensino se amplia (relativamente) e em que a Igreja consegue avaliar e enfrentar melhor os desafios da circulação das idéias pelo meio impresso, a emergência de uma literatura autodefinida como católica se apresenta como uma forma de apostolado.

Por que, nesse momento, jovens católicos mobilizam sua fé no domínio literário? C omo explicar que, pela primeira vez, a religião católica seja nos meios literários o objeto de uma reivindicação coletiva? A herança dos $C$ hateaubriand, dos Lamennais e dosVeuillot encontra então um eco particular no contexto de uma religião católica questionada pelos avanços republicanos e leigos. Para al guns herdeiros católicos, imbuídos de pretensões intelectuais, o declínio da condição de eclesiástico, do ensino livre, mas também a nova concorrência para o acesso a postos de poder no Estado provocada pela democratização escolar e a promoção dos valores republicanos pelas minorias protestantes e judaicas, embaralham as perspectivas (C harle, 1991, p. 234). D iante de um mundo social em mudança, que escapa gradualmente à influência da religião, esses herdeiros de um futuro tornado incerto elaboram uma retórica de combate para a defesa da I greja, reagindo contra o descrédito dos valores católicos de que são portadores. 0 grupo dos promotores do "renascimento literário" é socialmente homogêneo. Do ponto de vista geracional, constata se que nasceram nosanos de 1880, os do positivismo e da R epública leiga incipiente. São oriundos da aristocracia ou da burguesia católica (principalmente de província). Suas biografias revelam acidentes de percurso (morte prematura do pai, revezes de fortuna) que desviam suas trajetórias e reforçam sua adesão ao discurso de fim do mundo que a I greja então desenvolve (cf. Serry, 2001, pp. 91-111). 0 sacerdócio foi freqüentemente considerado - vários desses escritores, entre os mais ativos do "renascimento literário", entraram no seminário antes de renunciarem -, mas sua vocação literária acaba prevalecendo sobre a vocação sacerdotal. Para muitos, 0 
estatuto de convertido, um convívio com as ordenstercei ras e com o clero secular, uma prática religiosa assídua indicam um estado a meio caminho entre o leigo e o clérigo. A esmagadora maioria, devido a suas origens sociais elevadas, é animada pelo propósito de universalizar sua visão de mundo e agir para conformar a sociedade a ela. A vontade de ocupar posições adequadas à sua história familiar (prestigiosa, para alguns) não encontra eco nas carreiras eclesiásticas que uma I greja diminuída, separada do poder político que ela combate, é incapaz de oferecer. Pode-se dizer que 0 enfraquecimento da cultura católica durante todo 0 século XIX, e portanto as situações so ciais que 0 engajamento clerical possibilita (isso particularmente nos anos de 1880 e 1910), faz com que esses jovens que teriam sido "padres escritores" se tornem, sob o efeito das mutações sociais, "escritores padres".

U m dos principais animadores da literatura católica dessa época, $R$ obertValleryR adot, nascido em 1882, é filho de uma família da província de Yonne que conta com vários acadêmicos em seus quadros, um de seus tios tendo se casado com a filha de L ouis Pasteur. D esde o final do século XIX, porém, essa linhagem entrou num lento declínio social do qual Vallery-Radot é a primeiravítima. Em 1920, de maneira significativa, ele anuncia a seu confessor que pretende escrever um romance para" recordar essa burguesia de província que não existirá mais: 41 dessas velhas famílias desapareceram nos últimosvinte anos! N ão somosmais que trêsou quatro, no máximo, assistindo, melancólicos, à invasão brutal dos novos ricos do comércio e da indústria, dos funcionários sem princípios, sem tradição, com quem nada podemos ter em comum; estamos em país conquistado por bárbaros e nos refugiamos em nossos velhos livros, nossos velhos móveis, nossos caros preconceitos pueris, nossos costumes antiquados, nossa urbanidade fora de moda (Vallery-R adot, correspondência com dom Besse).

Para esses jovens pretendentes à carreira literária, reivindicar uma estética católica Ihes dá a possibilidade de val orizar a cultura da qual são detentores e de inscrever seu destino individual no destino coletivo de uma I greja animada por um discurso de combate. Essa especificidade católica de sua arte é o bilhete de ingresso no campo literário e permite constituir uma posição. M unido de um mercado potencial de leitores movidos pela luta contra a laicidade e atendendo ao desejo da hierarquia eclesial de se fazer presente nos debates de idéias, a emergência de um "renascimento literário católico" constitui um dosfenômenos principais do período que 
precede a Primeira Guerra.

A primeira revista do movimento, $\mathrm{L}$ es $\mathrm{C}$ ahiers de l'A mitié de $\mathrm{F}$ rance, criada no começo dos anos de 1910 por R obert Vallery-R adot e François M auriac, ocupa, em nome de um "catolicismo integral" que exclui qualquer outra concepção tanto em "estética como em moral e em sociologia" (1912, mar., p. 71), uma posição inédita no campo literário. Seu sucesso público bastante minguado não impede a revista, por meio das polêmicas que organiza, da publicação de precursores reconhecidos e dos primeiros sucessos de seus animadores, de dar crédito à idéia de um "renascimento literário católico". Embora nunca faltasse o entusiasmo aVallery-R adot, ainda assim é justificado afirmar com ele que, após um ano de publicação dos $C$ ahiers de l'A mitié, "doravante ninguém ignora que existe um lirismo católico, e que ao redor de Paul Claudel e de FrancisJammes há toda uma jovem geração ardentemente unida no mesmo amor ao C risto e à I greja" (1912, dez., p. 506). Contra o simbolismo declinante, contra o bastião da arte pela arte - a N ouvelle R evue $F$ rançaise de André Gide -, contra 0 neoclassicismo nacionalista dos discípulos de $C$ harles $M$ aurras, $L$ es $C$ ahiers de l'A mitié de $F$ rance constituem a primeira tentativa concreta de definir uma estética literária católica. A revista proporciona uma visi bilidade editorial a esses jovens autores e os meios de se imporem no campo literário. Ela quer ser o posto avançado de uma nova forma de militância para reconquistar o poder perdido pela I greja.

Sem entrar nos detal hes da história dessa revista, nem das outras inicia tivas que testemunham uma efervescência dos meios literários católicos, importa mencionar que, se esse "exército católico da pena", segundo a expressão de um autor da época, dá ao catolicismo uma visibilidade inédita, ele esbarrará nas exigências do clero em matéria de respeito à doutrina. $N$ essa época, com efeito, reivindicar para si o catolicismo não é concebível fora da I greja.A ssim, de uma maneira inversa à do campo literário, no qual a pertença católica é vista com suspeita e tida como incompatível com a arte, o clero manifesta uma clara desconfiança em relação aos artistas católicos, particularmente os convertidos, suspeitos de querer usurpar o magistério clerical. No momento em que é elaborada a linha editoral dos $C$ ahiers de l'A mitié, seus membros insistem na necessidade de publicar apenas autores cuja prática religiosa é comprovada. No entanto, eles afirmam também a necessidade de evitar todo dogmatismo excessivo, tanto mais porque uma prática religiosa completa não é garantia de uma produção literária de qualidade. A lógica das "regras da arte" e a do respeito à 
doutrina são com frequêencia inconciliáveis. Q uando os conflitos, por motivos tanto estéticos como políticos, se multiplicam entre os $C$ ahiers de I'A mitié e os religiosos que pertencem à revista (dominicanos), Vallery$R$ adot se queixa, em carta a M auriceVaussard, datada de 13 de junho de 1914, de que, se seu interlocutor religioso Ihe "nega toda competência para fazer nos $\mathrm{C}$ ahiers crítica doutrinal, só me resta retirar-me, pois não se cria um movimento com versos e romances". 0 laicato, num momento em que a Igreja é contestada, é uma posição privilegiada num campo intelectual fortemente governado pelo princípio de autonomia. A quaseimpossibilidade para os clérigos de intervir nos debates intelectuais proporciona uma autonomia relativa aos escritores que invocam o catolicismo. 0 convertido e filósofo tomista Jacques $\mathrm{M}$ aritain, grande figura do "renascimento literário", particularmente no apogeu do movimento nos anos de 1920, mobiliza esse argumento numa carta a seu diretor de consciência, R eginald Garrigou-Lagrange, em 8 de fevereiro de 1920:“M inha situação de leigo me permite atingir um público que sem isso jamais seria atingido". É nesse confronto, nascido do declínio do poder de uma Igreja obrigada a se apoiar nos leigos, que se impõe progressivamente uma nova figura, a do intelectual católico, capaz de afirmar-se contra a Igreja em nome do reconhecimento adquirido no campo literário.

D epois da Primeira Guerra, o "renascimento literário católico" estende seu campo de ação. $O$ B ulletin des É crivains $C$ atholiques de $C$ harles Luce, L es L ettres de Gaëtan Bernoville e sua "Semana dos Escritores C atólicos", os $C$ ahiers $C$ atholiques do abade $R$ oblot, $O$ R oseau d' $O r$ de Jacques $M$ aritain são algumas iniciativas, entre outras, que dão forma à nova presença do escritor/ intelectual católico.

As relações entre literatura e religião mostram-se em toda a sua complexidade à medida que se estabelecem as modalidades do lento trabalho dos atores do campo literário (ou intelectual) para conquistar uma autonomia (relativa) na prática de sua arte (e de seu poder crítico). A utonomia que eles conquistam tanto contra a religião como contra os poderes políticos ou econômicos. $\mathrm{N}$ o período entre guerras, a questão é: o que vem a ser um escritor ou um intelectual católico? A o mesmo tempo, é preciso considerar a capacidade de uma instituição total como a I greja, confronta da à "modernidade" pós-revolucionária - isto é, à emergência de um discurso que contesta seu poder social em nome de racionalidades (científicas, em particular) exteriores a seu controle -, de lutar contra 0 esboroamento de sua influência social. A criação progressiva, pela insti- 
tuição eclesial, de uma retórica antimoderna (a I greja como contra- socieda de) tem a ver com desafios internos, reunindo indivíduos que encontram no destino da instituição, da qual são em parte o produto, o meio de dar um sentido a seu próprio destino social.

As afinidades entre literatura e religião, identificáveis desde $0 \mathrm{G}$ énie du christianisme até o "renascimento literário católico", passam igualmente pela elaboração de uma estética católica integral. C ontudo, da mesma maneira como para a definição do escritor católico, não se constata nenhuma realização dessa estética. A s numerosas tentativas feitas nesse sentido esbarram numa dupla dificuldade: de um lado, o risco de questionar a moral católica; de outro, o de relativizar sua mensagem ao destiná la a ser uma estética entre outras - o que a "Verdade católica” não pode conceber. Participando, com François M auriac, daquela que será a última revista católica desse movimento de "renascimento" , V igile, o crítico Charles du Bos, convertido em 1927, resumia assim a "situação do escritor católiCO":

[...] nessa effera, o perigo da intervenção de um automatismo, seja ele qual for, eleva-se ao quadrado, pois, pelo simples fato de o escritor ser cristão, os descrentes já o vêem como um semi-autômato. Acaso Gide e tantos outros não estão sempre a repetir? "Vosso assento está garantido de antemão: não podeis nem escrever, nem pensar, nem mesmo talvez sentir de outro modo que não sois obrigados a pensar, a sentir e a escrever" (1954, pp. 240-241).

A análise dos vínculos entre literatura e religião não pode se contentar com uma análise da produção como tal, mesmo relacionada ao contexto. Ela requer uma reconstrução do quadro sociohistórico das relações dessas duas realidades sociais. Além de o trabalho sobre os textos tender com freqüência a negligenciar as lógicas e os interesses próprios a cada campo (intelectual, religioso, político), ele negligencia que a existência de uma "literatura católica", de uma "estética católica", de um "escritor católico" e de seu papel social tem a ver com lutas pelo poder de definição dessas noções. Possuir a capacidade de determinar (e de impor) os critérios de uma "literatura católica" é possuir as chaves de lutas intra-eclesiais, de lutas políticas quanto ao lugar da religião na sociedade e de lutas relacionadas ao poder social dos intelectuais. D epreender os traços estruturais que determinam as relações entre literatura e religião equivale a precaver-se contra os discursos que cada espaço produz para legitimar sua exis- 
tência. 0 que é particularmente verdadeiro em relação ao campo religioso, em que 0 arbitrário e a renovação só pretendem manifestar-se sob o aspecto de uma transcendência.

\section{Referências Bibliográficas}

A R Quivos da abadia de Ligugé. C orrespondências R obert Vallery- $R$ adot- $D$ om B esse. Arquivos do Círculo de Estudos Jacques e Raïssa M aritain, Kolbsheim. C arta de

Jacques M aritain a R eginald Garrigou-Lagrange, 8 de fevereiro de 1920.

A U beRT, R oger. (1965), "La liberté religieuse de M irari Vos au Syllabus”. C oncilium, 7. BÉn IC H o u, Paul. (1977), Letemps des prophètes: doctrines de l'âge romantique, Paris, G allimard. . (1996), L e sacre de l'écivain, 1750-1830: essai sur l'avènement d'un pouvoir spirituel laïque dans la F rance moderne. Paris, G allimard.

B NF. C arta de R obertVallery-R adot a M auriceVaussard, 13 de junho de 1914. Paris. B OU R DIEU, Pierre. (1992), L es règles del' art: genèse et strucure du dhamp littéraire. Paris, Seuil. C ALVET, Jean. (1922), "La renaissance religieuse dans la littérature catholique française”. $R$ evueT rimestrielle $C$ anadienne, 31 set.

C HAR LE, Christophe. (1990), N aissance des" intellectuels" (1880-1900). Paris, M inuit. . (1991), H istoire sociale de la F rance au X IX e siède. Paris, Seuil.

C Laudel, Paul. (1959), “M a conversion [1913]”. In:_____. C onversations dans le L oir-et-

C her: contads et arconstances. Paris, Gallimard. . (1973), C orrespondance (1908-1914). Paris, D esclée de Brouwer.

C ou GH, A ustin. (1986), Paris et R ome: les catholiques français et le Pape au XIX e siède. Paris, Éditions 0 uvrières.

DeNIs, abade C h. (1892), L'université catholique, 15 de maio, pp. 69-113.

D ERRÉ, Jean-R ené. (1962), L amennais, ses amis et le mouvement des idées à l'époque romantique. Paris, Klincksieck.

D ho m BR ES, N icole \& D h о m BR ES, Jean. (1989), N aissance d'un nouveau pouvoir: science et savants en $\mathrm{F}$ rance (1793-1824). Paris, Payot.

Du Bos, Charles. (1954), Journal V (1929). Paris, ÉditionsV ieux Colombier.

Durkheim, Émile. (1990), L'évolution pédagogique en F rance. Paris, PU F.

FER GU SO N, Priscilla Parkhurst. (1991), L a F rance nation littéraire. B ruxelas, Labor.

GaDiLle, Jacques (1969), “Autour de LouisVeuillot et de L'U nivers”. C ahier d'H istoire, t. 14. Gu Gelot , Frédéric. (1998), La conversion des intelleduels au catholidsisme en F rance, 18851935. Paris, C N R S Éditions.

LaGR ÉE, M ichel. (1999), La bénédidion de Prométhée: religion et technologie. Paris, Fayard. LAN GLOIS, C laude. (1997), “La naissance de l'intellectuel catholique”. In:C o LIN ,Pierre (dir.). Intellectuels chrétiens et esprits des années 1920, Paris, C erf, pp. 213-223. 
Les C ahiers de l'A mitié deF rance, mar.- dez. 1912.

Le Guillou, Louis، (1996), “Lamennais”. In: Laplan CHE, François (dir.). Les sciences religieuses, Paris, Beauchesne.

LeVILLAIn , Phillipe. (1994), "Les catholiques à l'épreuve: variations sur un verdict”. In: BIR N bau M , Pierre (dir.). L a F rance de l'A ffaire D reyfus, Paris, Gallimard, pp. 411-450.

Lo UÉ,T homas. (1996), "Les fils deTaine entre science et morale.: à propos du D isciple de Paul Bourget (1889)" . C ahiers d'H istoire R evue d'H istoire C ritique, 65: 44-61.

M ACher Ey, Pierre. (1996), "Louis de Bonald”. In: Laplan CHe, François (dir.). L es sciences religieuses, Paris, Beauchesne, pp. 76-77.

. (1996), “Joseph de M aistre”. In: LapLAn CHE, François(dir.). L es sciences religieuses, Paris, Beauchesne, pp. 441-442.

M AY EUR , Jean-M arie. (1991), L a séparation de l'É glise et del'É tat. Paris, Éditions O uvrières.

Pellet Ier , D enis. (1997), L es catholiques en F rance depuis 1815. Paris, La D écouverte.

Pier r ar D, Pierre. (1988), Les laïss dans l'É glise de F rance (X IX e-XX e). Paris, Éditions O uvrières.

. (1997), Juifs et catholiques français: d'E douard D rumont à Jacob K aplan (18861994 ). Paris, Cerf. . (1999), L ouisV euillot. Paris, B eauchesne.

PONTON , R emy. (1975), “N aissance du roman psychologique: capital culturel, capital social et stratégie littéraire à la fin du 19 e siècle". A des de la R echerche en Sciences Sodales, 4: 66-75, jul.

Poulat, Émile. (1984), “LouisVeuillot et son temps”. R evue del'Institut C atholiquede Paris. . (1996), H istoire, dogme et critique dans la crise moderniste. Paris, A lbin M ichel (1 ed. 1962).

R AIM OND, M ichel. (1967), La rise du roman: des lendemains du naturalisme aux années vingt. Paris, $C$ orti.

R EgAR D, M aurice (ed.). (1978), E ssai sur les révolutions: génie du christianisme. Paris, Gallimard.

R en An , Ernest. (1974), L a vie de Jésus. Paris, G allimard (folio) (1 ed. 1863).

SAPIRO, Gisèle. (2002), "La responsabilité de l'écrivain: de Paul Bourget à Jean-Paul Sartre". In: EIN FAT , M ichael \& JURT, Joseph (eds.). L e texte et le contexte: analyses du champ littéraire français ( $X I X{ }^{e}$ et $X X{ }^{e}$ siède), Étude du C entre F rançais de I'U niversité de Fribourg, t. 9. Berlim/ Paris,Verlag/ E dição da M SH , pp. 219-240.

Schn er D, R obert. (1968), L e X IX e siède: I'apogée de l'expansion européenne. Paris, PU F. SER RY, H ervé. (2001), “D éclin social et revendication identitai re: la'renaissance littérai re

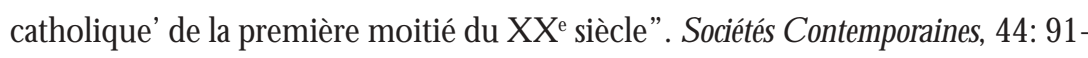
111, dez. 
. (2003), “C omment condamner la littérature? Contrôle doctrinal catholique et création littéraire au XX X sècle". "É tudes de L ettres, 4:89-109, U niversidade de Lausanne. . (2004), N aissance de l' intellectuel catholique. Paris, La D écouverte.

T RAn vo uEz,Y von. (1975), “R eligion, politique et civilisation chrétienne: Lamennais en 1817. Étude sur le premier tome de l'E ssai sur l'indifférence". In: D ER RÉ, Jean-R enéet. al. (orgs). C ivilisation drétienne: approche historique d'une idéologie (XV III - X X X siède), Paris, Beauchesne. Veuillot, François. (1912), “La neutralité littéraire”. L a C roix, 18 out. VIALA, Alain. (1988), "Effets de champ, effets de prisme”. L i ittérature, 70, maio.

\section{Resumo}

0 artigo delineia a história da emergência do "escritor católico" como uma nova figura intelectual naFrança pós R evolução de 1789, desde o surgimento do G éniedu dristianisme de Chateaubriand, passando pelo papel do abade Félicité de Lammenais, pelo do jornalista LouisVeuillot, pelos "neo-cristãos" dos anos de 1880 e 1890, até as primeiras manifestações do "renascimento literário católico" da década de 1910. Essa " renovação católica" teve de lidar com desafios propriamente literários, suscitados pela dinâmica orientada pelas regras da arte, ao lado de disputas doutrinárias no interior de uma Igreja com poder temporal declinante, confrontada com aemancipação dosleigos. 0 desvendamento desse processo histórico contribui para uma história social da crença no poder da arte e para uma reflexão acerca dos motivos intelectuais da crença na I greja como instituição. Palavras-chave: Sociologia dos intelectuais, H istória social do catolicismo; Literatura e Igreja; França1800-1914.

\section{Abstract}

The article outlines the historical rise of the "C atholic writer" as a new intellectual creature in France after the 1789 revolution, from appearence of $\mathrm{G}$ énie du $\mathrm{C}$ hristianisme by $C$ hateaubriand, though the roles performed by the abbot Félicité de Lammenais, by the journalist LouisVeuillot, or even by the "neo-C hristians" of 1880-1890, until the first signs of a "C atholic literary renaissance" during the decade of 1910. This "C atholic" renewal had to cope with literary challenges, $s 0$ to speak, raised by the dynamics oriented by the rules of art, besides other doctrinal disputes inside a Church whose temporal power was declining, as well as confronted with the lay emancipation.T he knowledge of that historical process contributes to a social history of belief in the power of art and

HervéSerry ésociólogo e pesquisador associado ao C.S.U. (I resco - Paris). also for an understanding about the intellectual founda-tions of belief in the $\mathrm{C}$ hurch as institution.

Keywords: Sociology of intellectuals; Social history of C atholicism; Literature and C hurch; France 1800-1914. 